\title{
Modification of the sterol profile in milk through feeding
}

\author{
S. Duong, ${ }^{1}$ N. Strobel, ${ }^{2}$ S. Buddhadasa, ${ }^{2}$ M. J. Auldist, ${ }^{3}$ W. J. Wales, ${ }^{3}$ P. J. Moate,${ }^{3}$ G. Cox,${ }^{4}$ J. D. Orbell, ${ }^{1}$ \\ and M. J. Cran ${ }^{1 *}$ \\ ${ }^{1}$ Institute for Sustainable Industries and Liveable Cities, Victoria University, PO Box 14428, Melbourne, Victoria, Australia, 8001 \\ ${ }^{2}$ National Measurement Institute, Australian Government, 1/153 Bertie Street, Port Melbourne, Victoria, Australia, 3207 \\ ${ }^{3}$ Department of Jobs, Precincts and Regions, 1301 Hazeldean Road, Ellinbank, Victoria, Australia, 3821 \\ ${ }^{4}$ Naturale Pty. Ltd., 249 East Maurice Road, Ringarooma, Tasmania, Australia, 7263
}

\section{ABSTRACT}

The fortification of milk with phytosterols is an increasingly common practice to enhance the sterol profile and offer consumers potential health benefits. This study investigated whether cattle feed can influence the profile of phytosterols and cholesterol in the milk produced as an alternative to direct fortification of milk. Five experiments were performed using feeds commonly used by Australian dairy farmers and selected formulated rumen-protected feeds. Statistical significances were observed for some individual plant sterols and cholesterol in milk under these differing feeding regimens compared with the respective controls. In the case of the phytosterols, where the daily recommended consumption is typically $2 \mathrm{~g}$ per day, the total phytosterols were $<0.12 \mathrm{mg} / 100 \mathrm{~mL}$ of milk. An experiment using a rumen-protected feed with high phytosterol levels suggested a decreased transfer of cholesterol to the milk by as much as $20 \%$, although further work is required to confirm these preliminary results. Overall, the study suggests that different feeding practices have minimal effect on the resulting sterol profile of the milk.

Key words: phytosterol, milk fortification, rumenprotected feed, cholesterol

\section{INTRODUCTION}

Over recent decades, health-conscious consumers have influenced the dairy market to supply a broad variety of milk products. This is generally achieved by the removal or addition of various compounds including fats, vitamins, and omega fatty acids (FA; Ben-Ishay et al., 2017; Yeh et al., 2017). More recently, interest has increased in the consumption of phytosterols, which

Received May 15, 2018.

Accepted March 12, 2019.

*Corresponding author: marlene.cran@vu.edu.au are produced by plants and have a chemical structure similar to cholesterol (Gylling et al., 2014). In humans, the consumption of high levels of phytosterols reduces the uptake of dietary cholesterol, and to compensate, the body produces cholesterol for metabolic functions (Gylling et al., 2014; Phang and Garg, 2014; Moreau et al., 2018). Detection of the cholesterol precursor lanosterol in the bloodstream is generally an indicator of metabolic or dietary blood cholesterol (Gylling et al., 2014). Phytosterols have also been associated with phytoestrogens due to similarities in their chemical structures. However, the classification of phytosterols as part of the phytoestrogen group is potentially controversial because some in vitro experiments (Mellanen et al., 1996; Waalkens-Berendsen et al., 1999) have demonstrated that phytosterols do not appear to activate estrogen receptors that would otherwise influence fertility (Rideout et al., 2012).

Fortification of milk nutrients is usually achieved by the direct addition of the nutrients to the final product, with this technique recently shown to enhance vitamin E, selenium, and levels of different FA in milk (Leduc et al., 2017; Meignan et al., 2017; Pfrimer et al., 2018). An alternative to the direct addition of nutrients can be achieved via natural means such as modification of the diet of the cows or biofortification, which can reduce the possibility of overfortifying milk, thus reducing the risk of potential health problems from overconsumption of the added macronutrients. This is particularly important because some studies have shown that a high phytosterol diet can reduce the levels of beneficial fat soluble vitamins in blood plasma in humans (Goncalves et al., 2011; Gylling et al., 2014).

Enhancement of the FA profile in milk through biofortification has enabled an understanding of the influence on milk quality, with a balanced nutritional diet being the key to successful enhancement (Kalač and Samková, 2010). Given that phytosterol FA esters (i.e., sterols with a FA moiety) comprise the major sterol conjugates found in the lipid portion of many plants (Moreau et al., 2018), feeding studies related to the 
modification of the FA profile of milk may offer some insight into the possibility of phytosterol biofortification through feeding and the challenges therein. Several researchers have documented the effect of various feed types on the resulting FA profiles of milk. These experiments have shown that cattle breed, FA content in the feed, and ruminal digestion are all factors that can influence the FA content in milk (Egger et al., 2009; Hristov et al., 2011; Baldinger et al., 2014; Samková et al., 2014). For example, Steinshamn (2010) reviewed experimental data from feeding trials using a variety of grassland legumes such as white clover, red clover, and lucerne and demonstrated that, in general, a difference in feed resulted in changes to the FA composition of milk when compared with the control.

Rumen-protected feeds are formulated to be protected from degradation in the rumen, allowing the cattle to adsorb the intended nutrients further down the digestive tract. Protection can be achieved by various methods that are primarily based on encapsulating the feed to increase the rumen uptake of oilseeds and oilseed meals, and rumen protection has been studied and used with varying degrees of success for over $30 \mathrm{yr}$. Studies have shown that milk quality and the FA composition of beef fat can be influenced by using rumen-protected feeds containing a broad range of macronutrients, FA, and AA (Gulati et al., 2000; Wang et al., 2013; Gómez et al., 2015; Pineda and Cardoso, 2015).

Several experiments have reported on the concentrations of phytosterols in humans and how these are influenced by diet (Rideout et al., 2012; Berciano and Ordovás, 2014; Huang et al., 2017; Moreau et al., 2018). However, few recent reports in the scientific literature have documented the phytosterol content in ruminant milk (Jensen, 2002). Furthermore, no published studies exist reporting how feeding practices might influence the phytosterol content of ruminant milk. The aim of the present study was therefore to determine the potential to enhance the sterol content in milk. This was achieved through 5 controlled feeding experiments in which the cows were subjected to a variety of different diets.

\section{MATERIALS AND METHODS}

\section{Feeding Experiments}

Four feeding experiments were conducted by researchers from the Department of Economic Development, Jobs, Transport and Resources (formerly known as the Department of Primary Industries), at the Ellinbank facilities in Victoria, Australia. This included (1 and 2) 2 pasture supplementation feeding experiments (Auld- ist et al., 2013; Akbaridoust et al., 2014; Auldist et al., 2014); (3) a tannin and cottonseed oil feeding experiment (Aprianita et al., 2014); and (4) a grape marc feeding experiment (Moate et al., 2014). In addition, a rumen-protected feeding experiment (5) was conducted at Naturale Pty Ltd. in Ringarooma, Tasmania, in 2015. A more detailed description of each of the feeding experiments is presented in the Supplemental Material (https://doi.org/10.3168/jds.2018-15067), including tables of the feed types and feed amounts.

Pasture Supplementation Experiment 1. In this experiment, which was performed in April-May 2010, 3 main feeding treatments were investigated to assess differences in the feeding mode and the type of feed supplements. At the start of this experiment, the cows were $227 \pm 72.8$ (mean \pm standard deviation) DIM. In this experiment, the feeding regimens included a standard practice control (SPCtrl) treatment (72 cows) and 2 pasture supplementation experiment (PSE) treatments (72 cows each) where cattle in all groups were initially grazed on ryegrass pasture where the pasture allowance per cow was approximately $14 \mathrm{~kg}$ of DM/d. In the SPCtrl group, the feed was supplemented twice daily with barley grain fed in the dairy and pasture silage fed in the paddock. Similar to the SPCtrl group, cows in the PSE1a treatment were also supplemented with barley grain and pasture silage, but these components were fed as a mixed ration on a feed pad. For the third treatment, PSE1b, cows were offered a supplement of barley grain, maize, lucerne hay, and maize silage, which was also offered as a mixed ration on a feed pad. To evaluate the influence of feeding amount, the groups were further divided into 4 groups of 9 cows that were each fed $6,8,10$, or $12 \mathrm{~kg}$ of supplement based on the DM content per day.

Pasture Supplementation Experiment 2. This feeding experiment was performed in October-November 2010 to assess differences in the feeding mode and the type of feed supplements. At the start of this experiment, the cows were $70 \pm 15.2$ (mean \pm standard deviation) DIM. Three main feeding treatments were investigated including a SPCtrl treatment where cattle were fed on ryegrass pasture supplemented with wheat grain in the dairy and pasture silage in the paddock (64 cows). A second feeding treatment based on pasture supplementation (PSE2a) involved cattle fed on the same ryegrass pasture as the SPCtrl treatment, with the cow's diet supplemented with wheat and corn grain, corn silage, and lucerne hay fed as a mixed ration on a feed pad (64 cows). A third dietary treatment (PSE2b) was investigated that involved cattle grazing ryegrass pasture diet supplemented with the same mixed ration as PSE2a but in which some of the wheat 
had been replaced with solvent-extracted canola meal (32 cows). The pasture allowance for all treatments was approximately $14 \mathrm{~kg}$ of $\mathrm{DM} / \mathrm{d}$ for each cow. To evaluate the influence of feeding amount, the SPCtrl and PSE2a groups were divided into 4 groups of 8 cows (per replicate) that were each fed $8,10,12$, or $14 \mathrm{~kg}$ of supplement based on the DM content per day. Cows on the PSE2b treatment were divided into 2 groups of 8 cows (per replicate) and were each fed 12 and $14 \mathrm{~kg}$ of supplement based on the DM content per day.

Tannin and Cottonseed Oil Feeding Experiment. This experiment was conducted in September 2010, and at the start of this experiment, the cows were $39 \pm 13$ (mean \pm standard deviation) DIM. Cows were fed a control diet or the control diet supplemented with $800 \mathrm{~g} / \mathrm{d}$ of tannin from black wattle, $800 \mathrm{~g} / \mathrm{d}$ of cottonseed oil, or $400 \mathrm{~g} / \mathrm{d}$ each of tannin and cottonseed oil. The experimental design was performed using a Latin square scheme for a duration of 16 wk. Each diet was implemented to the cows for $4 \mathrm{wk}$ before moving on to the next respective diet.

Grape Marc Feeding Experiment. This experiment was conducted during March 2011 and at the start of this experiment, the cows were $203 \pm 72.8$ (mean \pm standard deviation) DIM. This experiment included 3 dietary treatments: control, dried grape marc (DGM), and wet grape marc (WGM) feeds. All cows in the study were placed on the control diet for the first $3 \mathrm{wk}$ of the experiment before they were moved to their respective intended diets. The daily control diet consisted of $14 \mathrm{~kg}$ DM of alfalfa hay and $4.3 \mathrm{~kg}$ DM of concentrate mix; the DGM diet consisted of $9 \mathrm{~kg}$ DM of alfalfa hay, $4.3 \mathrm{~kg} \mathrm{DM}$ of concentrate mix, and $5 \mathrm{~kg}$ DM of DGM; and the WGM diet consisted of $9 \mathrm{~kg}$ DM of alfalfa hay, $4.3 \mathrm{~kg} \mathrm{DM}$ of concentrate mix, and $5 \mathrm{~kg}$ DM of WGM.

Rumen-Protected Feeding Experiment. This experiment was conducted in mid-September 2015 for a period of $4 \mathrm{wk}$. The cows were $195 \pm 30$ (mean \pm standard deviation) DIM. In this experiment, 7 cows were used with 4 dietary feeding treatments including control, sterol protected (SP) feed, omega protected (OP) feed containing eicosapentaenoic acid and docosahexaenoic acid, and canola-soybean protected (CSP) feed. Both the sterol and soybean-canola protected feeds contained high levels of plant sterols, with the sterol protected feed consisting of a phytosterol fatty ester paste and the soybean-canola consisting of natural phytosterols originating from the components. All the animals were placed on the control diet on the first 2 wk before moving to their respective diets. The daily control diet consisted of $3.6 \mathrm{~kg}$ DM of dairy herd concentrate (60\% corn and $40 \%$ wheat), $3.5 \mathrm{~kg}$ DM of maize silage, and approximately $10 \mathrm{~kg}$ DM of pasture. The daily protected feeds were the same as the control diet with the addition of $620 \mathrm{~g}$ of protected omega feed, $800 \mathrm{~g}$ of protected sterol feed, or 1,000 g of protected soybean-canola feed. Rumen protection of the feed was achieved using a protein encapsulation process with cinnamaldehyde (a nontoxic food additive) via a process similar to that reported by Gulati et al. (1999). In brief, the sterol fatty esters, canola oil-soybean oil, or omega eicosapentaenoic acid and docosahexaenoic acid were emulsified before cinnamaldehyde was added to the emulsified lipids to create cross-linkages between the emulsified oil and proteins. The mixture was then dried until it was a free-flowing powder. This type of protection allows the feed to avoid dehydrogenation in the rumen during the digestion process of the cattle (Gulati et al., 2000a).

In each set of experiments, representative samples of morning and afternoon milk were collected from individual cows over the last $2 \mathrm{~d}$ of the experiment using an inline meter (DeLaval International, Tumba, Sweden). Milk samples were combined and stored in opaque plastic containers and were immediately frozen at $-20^{\circ} \mathrm{C}$ before analysis to reduce minimal loss of sterol content. The authors acknowledge that because of the length of storage, change to the milk fat or composition is expected (Chang et al., 2012; García-Lara et al., 2012). However, because all the samples within the experiments were collected, stored, and analyzed at the same time, any degradation of the milk within the experiments would be similar, and therefore, comparisons are deemed to be valid. In addition, duplicate samples and comparisons to literature reports were found to be comparable for the cattle feed and milk with regard to sterol content (Gorban and Izzeldin, 1999; Piironen et al., 2002a; Reklewska et al., 2002; Ruibal-Mendieta et al., 2004; Food Standards Australia New Zealand, 2010).

\section{Reference Standards and Reagents}

Reference standards with a purity assay greater than 95\% were purchased from Sigma Aldrich (Sydney, Australia), including cholesterol, stigmasterol, stigmastanol, brassicasterol, lathosterol, lanosterol, 5b-cholestan-3aol, $\beta$-sitosterol, and campesterol (purity assay 65\%). All reference standards were prepared in heptane as 500 $\mathrm{mg} / \mathrm{L}$ stock solutions. An acid hydrolysis solution of $8 M$ hydrochloric acid diluted in ethanol was prepared before analysis. A saponification solution of $5 M$ potassium hydroxide (Sigma Aldrich), with the potassium 
hydroxide dissolved in water, was made up in ethanol to volume. $\mathrm{N}$-O-bis-(trimethylsilyl) trifluoroacetamide with $1 \%$ trimethylchlorosilane was obtained from Grace Davison (Columbia, MD); n-heptane, pyridine, and cyclohexane were obtained from Merck (Melbourne, Australia); and boiling chips were obtained from $\mathrm{BDH}$ (Sydney, Australia). Ultrapure, Type 1 water was used throughout the experiments and was obtained using a Millipore water purification system (Element A10; Millipore Sigma, Burlington, MA).

\section{Extraction of Phytosterols from Milk}

The milk and cattle feed were analyzed for their phytosterol content as per the method described by Duong et al. (2018). In brief, $5 \mathrm{~mL}$ of thawed milk was spiked with a surrogate standard ( $5 \beta$-cholestan-3 $\alpha$-ol), followed by the addition of $5 \mathrm{~mL}$ heptane, which was then hydrolyzed using hydrochloric acid ( $4 \mathrm{~mL}$ of $8 M$ ). The solution was incubated in a water bath at $80^{\circ} \mathrm{C}$ for $30 \mathrm{~min}$ and then allowed to cool to room temperature before the addition of $20 \mathrm{~mL}$ of ethanolic potassium hydroxide $(5 M)$. The mixture was again incubated for $30 \mathrm{~min}$ and allowed to cool to room temperature before the addition of $4 \mathrm{~mL}$ of Ultrapure, Type 1 water. The mixture was vortexed and allowed to settle or until 2 liquid layers were obtained. The organic layer was collected and evaporated to $1 \mathrm{~mL}$ using nitrogen gas and transferred to a sample vial. The extract in the sample vial was once again evaporated to dryness using nitrogen gas and derivatized using $300 \mu \mathrm{L}$ of $\mathrm{N}$-Obis-(trimethylsilyl) trifluoroacetamide and $700 \mu \mathrm{L}$ of a toluene-pyridine mixture before the vial was crimped, mixed, and incubated at $80^{\circ} \mathrm{C}$ for 20 min before analysis.

\section{GC-MS/Flame Ionization Detector Analysis}

An Agilent 7890 gas chromatograph (Agilent Technologies Inc., Santa Clara, CA) coupled with a 5975c MS detector and a flame ionization detector, using an HP-5MS capillary column (5\%-phenyl-methylpolysiloxane $30 \mathrm{~m} \times 0.25 \mu \mathrm{m} \times 0.25 \mu \mathrm{m}$ film thickness), were used to perform the analyses. The following oven program was used. The initial oven temperature of $245^{\circ} \mathrm{C}$ was held for $0.5 \mathrm{~min}$ followed by an increase to $265^{\circ} \mathrm{C}$ at $2^{\circ} \mathrm{C} / \mathrm{min}$ and then to $290^{\circ} \mathrm{C}$ at $3.5^{\circ} \mathrm{C} / \mathrm{min}$, which was held for $8 \mathrm{~min}$; a 7.5 -min postrun program at $240^{\circ} \mathrm{C}$ with a back-flush flow at $165.5 \mathrm{kPa}$ was then applied for a total run time of 32 min. Sample injection was performed at $310^{\circ} \mathrm{C}$ for all samples, with injection volumes of $1 \mu \mathrm{L}$ with a 1:20 split for cholesterol analysis in milk and $2 \mu \mathrm{L}$ splitless for phytosterol analyses in milk.

\section{Statistical Analysis}

A one-way ANOVA was applied to the data, which included comparisons of the pooled sterol contents between the feeding type and the pooled sterol contents from the feeding rates where applicable. This comparison allowed for the identification of any significant differences within the group that could demonstrate the effect of feed on milk with regard to sterol content. In addition, where significant differences were found in any of the analyses, a post hoc $t$-test was performed to determine and identify the possible significance. Statistical calculations were performed using IBM SPSS statistics version 23 software (Armonk, NY), and statistically significant differences between treatments were declared when $P<0.05$.

\section{RESULTS AND DISCUSSION}

\section{Pasture Supplementation Experiment 1}

A summary of the detected sterol levels measured in the milk from the first mixed ration feeding experiment is presented in Table 1, with the results a combined mean from the different feeding rates for the same treatment. In this experiment, $\beta$-sitosterol, brassicasterol campestanol, and stigmasterol were detected at $<0.02 \mathrm{mg} / 100 \mathrm{~mL}$, with total phytosterols detected at $<0.12 \mathrm{mg} / 100 \mathrm{~mL}$. Differences existed $(P<0.05)$ in the lathosterol levels for PSE1a and PSE1b, with mean lathosterol levels in milk produced under the PSE1a regimen $15 \%$ higher than in milk produced under the PSE1b regimen. Lathosterol was not detected in the feed samples, and in this case, both the SPCtrl and PSE1a shared the same feeding regimen, with the only difference in the method of offering the supplements to the cows. This change was not observed for the SPCtrl, where the cows on this diet were fed barley grain $(75 \%)$ and ryegrass silage (25\%) supplements in the paddock, whereas those on the PSE1a were given the same feed but from concrete feed pads. The results suggest that levels of lathosterol in milk may be influenced by the difference in the feed from PSE1a and PSE1b even though lathosterol was not present in either feed. The main difference in the feed composition is the presence of maize grain and maize silage in the PSE1b, which may have contributed to the lower lathosterol content in the milk, although the mechanism for this is unclear.

The effects of the quantity of feed given to the animals was explored with the results calculated as the mean value of all the same feed rates over the different feeding regimens. As shown in Table 2, there were no effects on the sterol contents in milk as a result of different feeding rates. In a concurrent study, milk yield results 
Table 1. Sterol contents from milk produced by cows fed the diet from pasture supplementation experiment 1: influence of feed type

\begin{tabular}{|c|c|c|c|c|c|c|}
\hline Sterol $^{1}$ & $\begin{array}{l}\text { Feeding } \\
\text { regimen }\end{array}$ & $\mathrm{N}$ & $\begin{array}{l}\text { Mean sterol } \\
\text { content, } \\
\mathrm{mg} / 100 \mathrm{~mL}\end{array}$ & $\mathrm{SE}$ & $\begin{array}{l}\text { Minimum, } \\
\mathrm{mg} / 100 \mathrm{~mL}\end{array}$ & $\begin{array}{l}\text { Maximum, } \\
\mathrm{mg} / 100 \mathrm{~mL}\end{array}$ \\
\hline \multirow[t]{4}{*}{ Cholesterol } & SPCtrl & 49 & 14.00 & 0.37 & 10.65 & 18.98 \\
\hline & PSE1a & 49 & 14.44 & 0.35 & 10.41 & 21.21 \\
\hline & PSE1b & 51 & 14.69 & 0.32 & 10.95 & 21.39 \\
\hline & Average & & 14.38 & 0.20 & 10.41 & 21.39 \\
\hline \multirow[t]{4}{*}{ Lathosterol } & SPCtrl & 49 & 0.18 & $<0.02$ & 0.09 & 0.30 \\
\hline & PSE1a & 49 & $0.20^{\mathrm{a}}$ & $<0.02$ & 0.08 & 0.30 \\
\hline & PSE1b & 51 & $0.17^{\mathrm{b}}$ & $<0.02$ & 0.08 & 0.34 \\
\hline & Average & & 0.18 & $<0.02$ & 0.08 & 0.34 \\
\hline \multirow[t]{4}{*}{ Campesterol } & SPCtrl & 49 & 0.04 & $<0.02$ & 0.03 & 0.12 \\
\hline & PSE1a & 49 & 0.04 & $<0.02$ & $<0.02$ & 0.07 \\
\hline & PSE1b & 51 & 0.04 & $<0.02$ & 0.02 & 0.10 \\
\hline & Average & & 0.04 & $<0.02$ & $<0.02$ & 0.12 \\
\hline \multirow[t]{4}{*}{ Lanosterol } & SPCtrl & 49 & 0.24 & $<0.02$ & 0.13 & 0.55 \\
\hline & PSE1a & 49 & 0.22 & $<0.02$ & 0.14 & 0.37 \\
\hline & PSE1b & 51 & 0.21 & $<0.02$ & 0.02 & 0.41 \\
\hline & Average & & 0.22 & $<0.02$ & 0.02 & 0.55 \\
\hline
\end{tabular}

${ }^{\mathrm{a}, \mathrm{b}}$ For each type of sterol, means followed by different superscripts were significantly different within the group and identified specifically after a post hoc analysis between the superscripted treatments $(P<0.05)$. Lathosterol $P$-values: a and $\mathrm{b}=0.03$.

${ }^{1}$ Total phytosterols, campestanol, stigmasterol, stigmastanol, and $\beta$-sitosterol were less than the limit of reporting.

${ }^{2} \mathrm{SPCtrl}=$ standard practice control; PSE1a and PSE1b = pasture supplementation experiment (PSE) 1a and $1 \mathrm{~b}$, respectively.

were shown to significantly increase at higher rates (Auldist et al., 2013) so the results in the present study suggest that an increase in milk yield or the amount of feed does not appear to influence total phytosterol content with the exception of lathosterol content.

\section{Pasture Supplementation Experiment 2}

A summary of the results from the second mixed ration feeding experiment are presented in Table 3, which shows a comparison between the mean sterol content of

Table 2. Sterol contents from milk produced by cows fed the diet from pasture supplementation experiment 1: influence of feed rate

\begin{tabular}{|c|c|c|c|c|c|c|}
\hline Sterol $^{1}$ & $\begin{array}{l}\text { Feeding } \\
\text { rate, } \mathrm{kg} / \mathrm{d}\end{array}$ & $\mathrm{N}$ & $\begin{array}{l}\text { Mean sterol } \\
\text { content, } \\
\mathrm{mg} / 100 \mathrm{~mL}\end{array}$ & $\mathrm{SE}$ & $\begin{array}{l}\text { Minimum, } \\
\mathrm{mg} / 100 \mathrm{~mL}\end{array}$ & $\begin{array}{l}\text { Maximum, } \\
\mathrm{mg} / 100 \mathrm{~mL}\end{array}$ \\
\hline \multirow[t]{5}{*}{ Cholesterol } & 6 & 36 & 14.28 & 0.44 & 10.65 & 21.21 \\
\hline & 8 & 36 & 14.46 & 0.38 & 10.41 & 18.06 \\
\hline & 10 & 37 & 14.50 & 0.46 & 11.74 & 21.39 \\
\hline & 12 & 40 & 14.28 & 0.32 & 11.29 & 18.71 \\
\hline & Average & & 14.38 & 0.20 & 10.41 & 21.39 \\
\hline \multirow[t]{5}{*}{ Lathosterol } & 6 & 36 & 0.18 & $<0.02$ & 0.09 & 0.34 \\
\hline & 8 & 36 & 0.17 & $<0.02$ & 0.08 & 0.30 \\
\hline & 10 & 37 & 0.18 & $<0.02$ & 0.10 & 0.27 \\
\hline & 12 & 40 & 0.18 & $<0.02$ & 0.09 & 0.27 \\
\hline & Average & & 0.18 & $<0.02$ & 0.08 & 0.34 \\
\hline \multirow[t]{5}{*}{ Campesterol } & 6 & 36 & 0.04 & $<0.02$ & $<0.02$ & 0.07 \\
\hline & 8 & 36 & 0.04 & $<0.02$ & 0.02 & 0.12 \\
\hline & 10 & 37 & 0.04 & $<0.02$ & 0.03 & 0.10 \\
\hline & 12 & 40 & 0.04 & $<0.02$ & 0.02 & 0.06 \\
\hline & Average & & 0.04 & $<0.02$ & $<0.02$ & 0.12 \\
\hline \multirow[t]{5}{*}{ Lanosterol } & 6 & 36 & 0.23 & $<0.02$ & 0.14 & 0.37 \\
\hline & 8 & 36 & 0.24 & $<0.02$ & 0.18 & 0.55 \\
\hline & 10 & 37 & 0.21 & $<0.02$ & 0.02 & 0.31 \\
\hline & 12 & 40 & 0.22 & $<0.02$ & 0.13 & 0.41 \\
\hline & Average & & 0.22 & $<0.02$ & 0.02 & 0.55 \\
\hline
\end{tabular}

${ }^{1}$ Total phytosterols, campestanol, stigmasterol, stigmastanol, and $\beta$-sitosterol were less than the limit of reporting. 
each feeding regimen and feeding rate. Similar to the results in the first mixed ration feeding experiment, $\beta$-sitosterol, brassicasterol campestanol, and stigmasterol were detected at $<0.02 \mathrm{mg} / 100 \mathrm{~mL}$ with total phytosterols detected at $<0.12 \mathrm{mg} / 100 \mathrm{~mL}$. A comparison between the 3 feeding regimens of this experiment showed differences for cholesterol, lathosterol, campesterol, and lanosterol. A further post hoc analysis was performed on these individual sterols, and the results indicated that the levels in milk were influenced by the differences in feeding regimens. In milk produced under the PSE2a diet, cholesterol and lanosterol contents were lower when compared with milk produced under the PSE2b diet. The main difference between the PSE2a and PSE2b is the addition of protein in the form of canola meal (16\%) and a lower amount of crushed wheat in the PSE2b diet (reduced from 39 to 23\%). Although the reasons for the increased cholesterol and lanosterol in the milk produced by cows fed the higher protein diet are unclear, some evidence exists that lanosterol can reverse protein aggregation (Zhao et al., 2015). The results also show that milk produced by cows fed under both PSE2a and PSE2b contained the same mean lathosterol content, which was lower than the milk from the SPCtrl diet. Moreover, the campesterol level in milk was observed to be highest in the SPCtrl group.
A comparison of total phytosterol content in the feed at the $13.5 \mathrm{~kg}$ of DM rate was $13,200,12,300$, and $13,500 \mathrm{mg}$ for the control, PSE2a, and PSE2b, respectively, with trace levels of cholesterol (Duong et al., 2018). This experiment suggests that the addition of protein into the feed in the form of solvent-extracted canola meal may increase the levels of cholesterol and lanosterol in the milk produced when compared with the PSE2a milk. Although the reasons for this are unclear, research by Strzałkowska et al. (2010) showed that in a year-long experiment under the same feeding regimen, cholesterol content was influenced by the time of year, the stage of lactation, and SCC.

The effects of the quantity of feed given to the cows were also explored with the results calculated as the mean value of all the same feed amounts over the different feeding regimens. In this case, statistical comparisons between the mean feed rates across the different regimens showed differences in the levels of campesterol as shown in Table 4. However, the results overall were considered to be insignificant between the groups.

\section{Tannin and Cottonseed Oil Feeding Experiment}

In the tannin and cottonseed oil feeding experiment, sterol profiles did not differ in the milk produced by the cows given the feeds with tannin, cottonseed oil, or

Table 3. Sterol contents from milk produced by cows fed the diet from pasture supplementation experiment 2: influence of feed type

\begin{tabular}{|c|c|c|c|c|c|c|}
\hline Sterol $^{1}$ & $\begin{array}{l}\text { Feeding } \\
\text { regimen }\end{array}$ & $\mathrm{N}$ & $\begin{array}{l}\text { Mean sterol } \\
\text { content, } \\
\mathrm{mg} / 100 \mathrm{~mL}\end{array}$ & $\mathrm{SE}$ & $\begin{array}{l}\text { Minimum, } \\
\mathrm{mg} / 100 \mathrm{~mL}\end{array}$ & $\begin{array}{l}\text { Maximum, } \\
\mathrm{mg} / 100 \mathrm{~mL}\end{array}$ \\
\hline \multirow[t]{4}{*}{ Cholesterol } & SPCtrl & 25 & 12.89 & 0.24 & 11.12 & 15.68 \\
\hline & PSE2a & 23 & $12.24^{\mathrm{a}}$ & 0.13 & 11.19 & 13.07 \\
\hline & PSE2b & 15 & $13.07^{\mathrm{b}}$ & 0.19 & 11.54 & 14.58 \\
\hline & Average & & 12.70 & 0.12 & 11.12 & 15.68 \\
\hline \multirow[t]{4}{*}{ Lathosterol } & SPCtrl & 25 & $0.148^{\mathrm{a}}$ & $<0.02$ & 0.08 & 0.28 \\
\hline & PSE2a & 23 & $0.126^{\mathrm{b}}$ & $<0.02$ & 0.09 & 0.17 \\
\hline & PSE2b & 15 & $0.126^{\mathrm{b}}$ & $<0.02$ & 0.08 & 0.16 \\
\hline & Average & & 0.135 & $<0.02$ & 0.08 & 0.28 \\
\hline \multirow[t]{4}{*}{ Campesterol } & SPCtrl & 25 & $0.050^{\mathrm{a}}$ & $<0.02$ & 0.03 & 0.08 \\
\hline & PSE2a & 23 & $0.040^{\mathrm{b}}$ & $<0.02$ & 0.03 & 0.06 \\
\hline & PSE2b & 15 & 0.043 & $<0.02$ & 0.03 & 0.05 \\
\hline & Average & & 0.045 & $<0.02$ & 0.03 & 0.08 \\
\hline \multirow[t]{4}{*}{ Lanosterol } & SPCtrl & 25 & 0.17 & $<0.02$ & 0.10 & 0.35 \\
\hline & PSE2a & 23 & $0.15^{\mathrm{a}}$ & $<0.02$ & 0.10 & 0.20 \\
\hline & PSE2b & 15 & $0.20^{\mathrm{b}}$ & $<0.02$ & 0.16 & 0.25 \\
\hline & Average & & 0.17 & $<0.02$ & 0.10 & 0.35 \\
\hline
\end{tabular}

\footnotetext{
${ }^{a, b}$ For each type of sterol, means followed by different superscripts were significantly different within the group and identified specifically after a post hoc analysis between the superscripted treatments $(P<0.05)$. Cholesterol $P$-values: a and $\mathrm{b}=0.02$, lathosterol $P$-values: $\mathrm{a}=0.03$ and $\mathrm{b}=0.07$, campesterol $P$-values: a and $\mathrm{b}=0.00$, lanosterol $P$-values: $\mathrm{a}$ and $\mathrm{b}=0.00$.

${ }^{1}$ Total phytosterols, campestanol, stigmasterol, stigmastanol, and $\beta$-sitosterol were less than the limit of reporting.

${ }^{2} \mathrm{SPCtrl}=$ standard practice control; PSE2a and PSE2b = pasture supplementation experiment (PSE) 2a and $2 \mathrm{~b}$, respectively.
} 
Table 4. Sterol contents from milk produced by cows fed the diet from pasture supplementation experiment 2: influence of feed rate

\begin{tabular}{|c|c|c|c|c|c|c|}
\hline Sterol $^{1}$ & $\begin{array}{l}\text { Feeding } \\
\text { rate, } \mathrm{kg} / \mathrm{d}\end{array}$ & $\mathrm{N}$ & $\begin{array}{l}\text { Mean sterol } \\
\text { content, } \\
\mathrm{mg} / 100 \mathrm{~mL}\end{array}$ & $\mathrm{SE}$ & $\begin{array}{l}\text { Minimum, } \\
\mathrm{mg} / 100 \mathrm{~mL}\end{array}$ & $\begin{array}{l}\text { Maximum, } \\
\mathrm{mg} / 100 \mathrm{~mL}\end{array}$ \\
\hline \multirow[t]{5}{*}{ Cholesterol } & 8 & 12 & 12.50 & 0.26 & 11.22 & 13.99 \\
\hline & 10 & 12 & 13.31 & 0.34 & 11.21 & 15.68 \\
\hline & 12 & 21 & 12.69 & 0.18 & 11.12 & 14.02 \\
\hline & 13.5 & 18 & 12.42 & 0.22 & 11.19 & 14.58 \\
\hline & Average & & 12.70 & 0.12 & 11.12 & 15.68 \\
\hline \multirow[t]{5}{*}{ Lathosterol } & 8 & 12 & 0.12 & $<0.02$ & 0.08 & 0.22 \\
\hline & 10 & 12 & 0.15 & $<0.02$ & 0.10 & 0.28 \\
\hline & 12 & 21 & 0.13 & $<0.02$ & 0.08 & 0.19 \\
\hline & 13.5 & 18 & 0.14 & $<0.02$ & 0.11 & 0.18 \\
\hline & Average & & 0.13 & $<0.02$ & 0.08 & 0.28 \\
\hline \multirow[t]{5}{*}{ Campesterol } & 8 & 12 & $0.05^{\mathrm{a}}$ & $<0.02$ & 0.04 & 0.07 \\
\hline & 10 & 12 & 0.05 & $<0.02$ & 0.03 & 0.08 \\
\hline & 12 & 21 & 0.04 & $<0.02$ & 0.03 & 0.07 \\
\hline & 13.5 & 18 & $0.04^{\mathrm{b}}$ & $<0.02$ & 0.03 & 0.06 \\
\hline & Average & & 0.04 & $<0.02$ & 0.03 & 0.08 \\
\hline \multirow[t]{5}{*}{ Lanosterol } & 8 & 12 & 0.18 & $<0.02$ & 0.14 & 0.30 \\
\hline & 10 & 12 & 0.18 & $<0.02$ & 0.14 & 0.35 \\
\hline & 12 & 21 & 0.17 & $<0.02$ & 0.13 & 0.25 \\
\hline & 13.5 & 18 & 0.15 & $<0.02$ & 0.10 & 0.23 \\
\hline & Average & & 0.17 & $<0.02$ & 0.10 & 0.35 \\
\hline
\end{tabular}

${ }^{a, b}$ For each type of sterol, means followed by different superscripts were significantly different within the group and identified specifically after a post hoc analysis between the superscripted treatments $(P<0.05)$. Campesterol $P$-values: a and $\mathrm{b}=0.00$.

${ }^{1}$ Total phytosterols, campestanol, stigmasterol, stigmastanol, and $\beta$-sitosterol were less than the limit of reporting.

a mix of tannin and cottonseed oil, as shown in Table 5. Even though cottonseed oil is a naturally rich source of phytosterols, its addition to the cattle diet did not enhance total phytosterol content in the milk in this study. In humans, the consumption of high levels of phytosterols is usually reflected in the plasma levels and a decrease in low-density lipoprotein cholesterol is also observed (Ostlund et al., 1999; Kritchevsky and Chen, 2005). It is suspected that the same effect may result when cows are fed a diet supplemented in phy-

Table 5. Sterol contents from milk produced by cows fed the diet from the tannin and cottonseed oil experiment

\begin{tabular}{|c|c|c|c|c|c|c|}
\hline Sterol $^{1}$ & $\begin{array}{l}\text { Feeding } \\
\text { regimen }\end{array}$ & $\mathrm{N}$ & $\begin{array}{l}\text { Mean sterol } \\
\text { content, } \\
\mathrm{mg} / 100 \mathrm{~mL}\end{array}$ & $\mathrm{SE}$ & $\begin{array}{l}\text { Minimum, } \\
\mathrm{mg} / 100 \mathrm{~mL}\end{array}$ & $\begin{array}{l}\text { Maximum, } \\
\mathrm{mg} / 100 \mathrm{~mL}\end{array}$ \\
\hline \multirow[t]{5}{*}{ Cholesterol } & Control & 7 & 12.26 & 0.36 & 11.33 & 13.83 \\
\hline & CSO & 8 & 12.60 & 0.62 & 10.40 & 15.93 \\
\hline & TANN & 8 & 12.74 & 0.88 & 9.93 & 17.65 \\
\hline & TCSO & 10 & 12.42 & 0.35 & 10.62 & 13.81 \\
\hline & Average & & 12.51 & 0.28 & 9.93 & 17.65 \\
\hline \multirow[t]{5}{*}{ Lathosterol } & Control & 7 & 0.17 & 0.02 & 0.11 & 0.28 \\
\hline & $\mathrm{CSO}$ & 8 & 0.17 & 0.03 & 0.07 & 0.36 \\
\hline & TANN & 8 & 0.13 & $<0.02$ & 0.07 & 0.22 \\
\hline & TCSO & 10 & 0.15 & 0.02 & 0.09 & 0.27 \\
\hline & Average & & 0.15 & $<0.02$ & 0.07 & 0.36 \\
\hline \multirow[t]{5}{*}{ Lanosterol } & Control & 7 & 0.21 & 0.03 & 0.12 & 0.30 \\
\hline & CSO & 8 & 0.18 & 0.03 & 0.05 & 0.30 \\
\hline & TANN & 8 & 0.19 & 0.03 & 0.12 & 0.29 \\
\hline & TCSO & 10 & 0.19 & 0.02 & 0.07 & 0.29 \\
\hline & Average & & 0.19 & $<0.02$ & 0.05 & 0.30 \\
\hline
\end{tabular}

${ }^{1}$ Total phytosterols, campestanol, campesterol, stigmasterol, stigmastanol, and $\beta$-sitosterol were less than the limit of reporting.

${ }^{2} \mathrm{CSO}=$ cottonseed oil; TANN $=$ tannin; $\mathrm{TCSO}=$ tannin and cottonseed oil. 
tosterols that is in excess of their normal consumption. Future work to analyze the blood plasma may aid in the understanding of the cow metabolism of phytosterols.

\section{Grape Marc Feeding Experiment}

The grape marc feeding experiment showed significant differences in the lanosterol levels between the feeding regimens, as shown in Table 6 . It was observed that the mean lanosterol content was highest in the milk from the animals fed on the control diet and lowest in the milk from those feds on the DGM feed; however, this was not reflected in the cholesterol results for the different feed types. Examination of the phytosterol content in the respective diets showed that the control diet contained the lowest amount of phytosterols, with 4,254 mg compared with the WGM and DGM, which contained 9,922 mg (Duong et al., 2018). The results suggest that high phytosterol levels may affect the endogenous synthesis of lanosterol, because this is generally observed in human subjects ingesting a high plant sterol diet (Ostlund, 2002; Kritchevsky and Chen, 2005).

In this case, the WGM and DGM diets were fed at the same weight based on the amount of DM in the feed. This further suggests that the moisture level in the feed may have some influence on the metabolism and digestion of the feed, which may decrease phytosterol absorption and increase endogenous lanosterol levels in the milk, which are a metabolic precursor for cholesterol (Jäpelt and Jakobsen, 2013). The total amounts of phytosterols detected were less than $0.12 \mathrm{mg} / 100 \mathrm{~mL}$ in all cases, which suggests that the feeding of either form of grape marc to dairy cows did not enhance total phytosterol levels in milk.

\section{Rumen-Protected Feeding Experiment}

Similar to the previous experiments, the total phytosterol content found in all milk samples under the rumen-protected feeds was $<0.12 \mathrm{mg} / 100 \mathrm{~mL}$. As shown in Table 7 , significantly higher levels of cholesterol, lanosterol, and lathosterol levels in the milk were found in animals fed the OP diet, with milk produced from the SP and CSP feed supplements resulting in the lowest cholesterol content. In humans, the consumption of phytosterols is suggested to reduce dietary cholesterol and regulate metabolic synthesis of cholesterol. The present study suggests that similar to humans, the consumption of high sterol contents by cattle may influence the metabolic synthesis of cholesterol, resulting in a reduced cholesterol content expressed in the bovine milk (Lichtenstein and Deckelbaum, 2001; Kritchevsky and Chen, 2005; Ostlund, 2007). Given that the lathosterol levels in the milk from the SP and the CSP feed experiments were both lower than the control and OP

Table 6. Sterol contents from milk produced by cows fed the diet from the grape marc experiment

\begin{tabular}{|c|c|c|c|c|c|c|}
\hline Sterol $^{1}$ & $\begin{array}{l}\text { Feeding } \\
\text { type }^{2}\end{array}$ & $\mathrm{~N}$ & $\begin{array}{l}\text { Mean sterol } \\
\text { content, } \\
\mathrm{mg} / 100 \mathrm{~mL}\end{array}$ & $\mathrm{SE}$ & $\begin{array}{l}\text { Minimum, } \\
\mathrm{mg} / 100 \mathrm{~mL}\end{array}$ & $\begin{array}{l}\text { Maximum, } \\
\mathrm{mg} / 100 \mathrm{~mL}\end{array}$ \\
\hline \multirow[t]{4}{*}{ Cholesterol } & Control & 25 & 16.47 & 0.54 & 11.99 & 22.67 \\
\hline & DGM & 20 & 15.43 & 0.57 & 11.21 & 20.97 \\
\hline & WGM & 21 & 16.46 & 0.59 & 11.77 & 23.77 \\
\hline & Total & 66 & 16.15 & 0.33 & 11.21 & 23.77 \\
\hline \multirow[t]{4}{*}{ Lathosterol } & Control & 25 & 0.11 & $<0.02$ & 0.02 & 0.21 \\
\hline & DGM & 20 & 0.12 & $<0.02$ & 0.06 & 0.23 \\
\hline & WGM & 21 & 0.13 & $<0.02$ & 0.08 & 0.21 \\
\hline & Total & 66 & 0.12 & $<0.02$ & 0.02 & 0.23 \\
\hline \multirow[t]{4}{*}{ Campesterol } & Control & 25 & $<0.02$ & $<0.02$ & 0.03 & 0.07 \\
\hline & DGM & 20 & $<0.02$ & $<0.02$ & 0.01 & 0.07 \\
\hline & WGM & 21 & $<0.02$ & $<0.02$ & 0.03 & 0.08 \\
\hline & Total & 66 & $<0.02$ & $<0.02$ & 0.01 & 0.08 \\
\hline \multirow[t]{4}{*}{ Lanosterol } & Control & 25 & $0.26^{\mathrm{a}}$ & $<0.02$ & 0.12 & 0.56 \\
\hline & DGM & 20 & $0.18^{\mathrm{b}}$ & $<0.02$ & 0.06 & 0.35 \\
\hline & WGM & 21 & 0.22 & $<0.02$ & 0.12 & 0.37 \\
\hline & Total & 66 & 0.22 & $<0.02$ & 0.06 & 0.56 \\
\hline
\end{tabular}

\footnotetext{
${ }^{a, b}$ For each type of sterol, means followed by different superscripts were significantly different within the group and identified specifically after a post hoc analysis between the superscripted treatments $(P<0.05)$. Lanosterol $P$-values: a and $\mathrm{b}=0.003$.

${ }^{1}$ Total phytosterols, campestanol, stigmasterol, stigmastanol, and $\beta$-sitosterol were less than the limit of reporting.

${ }^{2} \mathrm{DGM}=$ dried grape marc; $\mathrm{WGM}=$ wet grape marc.
} 
feed, this is in accordance with observations in humans where low levels of lathosterol in blood plasma are consistent with lower cholesterol.

The phytosterol content in the protected portion of the OP, CSP, and SP feeds contained total plant sterols of $1,319,2,593$, and $6,673 \mathrm{mg}$, respectively. The results show that levels of cholesterol in the milk produced by cows fed the high plant sterol SP and CSP diets were 22 and $11 \%$ lower than the control, respectively. In the case of the OP feed, which contained relatively high amounts of protected phytosterol, it also contained 799 mg of cholesterol, which may have interfered with plant sterol absorption.

In addition, the results for both the phytosterol and cholesterol contents for the milk produced were within normal range compared with nutritional panels and previous studies (Gorban and Izzeldin, 1999; Piironen et al., 2002b; Reklewska et al., 2002; Food Standards Australia New Zealand, 2010). Although this experiment was limited in the number of samples, particularly with regard to the $\mathrm{OP}$ treatment, the results indicate that cholesterol levels may be influenced by rumenprotected feeding, and further experiments would be needed to confirm the results. In all cases, $\beta$-sitosterol was detected at $<0.02 \mathrm{mg} / 100 \mathrm{~mL}$ for this experiment.

\section{Overview}

Overall, the levels of cholesterol measured in the milk samples from 5 feeding experiments ranged from 10.3 to $24 \mathrm{mg} / 100 \mathrm{~mL}$, and the majority of the milk samples contained less than $0.12 \mathrm{mg} / 100 \mathrm{~mL}$ of total phytosterols. The major sterols found in the milk were cholesterol, lathosterol, and lanosterol, the latter being a precursor sterol for cholesterol (Jäpelt and Jakobsen, 2013). Other plant sterols detected in the milk samples included campesterol and $\beta$-sitosterol but at minor or trace levels. In a recent study, the phytosterol content in the cattle feed used for this present study, lanosterol, and lathosterol were not detected (Duong et al., 2018). Given that both lanosterol and lathosterol were found in the milk, it suggested that their presence in milk was a result of endogenous synthesis. In general, the rumenprotected feeds containing high phytosterol contents produced milk with cholesterol levels 11 to $22 \%$ lower than the control.

The results of these feeding experiments demonstrate that certain feeds consumed by the cattle can influence individual sterol contents in bovine milk, including lanosterol, lathosterol, campesterol, and cholesterol, but only to a minor extent. Changes were observed between

Table 7. Sterol contents from milk produced by cows fed the diet from the rumen-protected experiment

\begin{tabular}{|c|c|c|c|c|c|c|}
\hline Sterol $^{1}$ & $\begin{array}{l}\text { Feeding } \\
\text { type }^{2}\end{array}$ & $\mathrm{~N}$ & $\begin{array}{l}\text { Mean sterol } \\
\text { content, } \\
\mathrm{mg} / 100 \mathrm{~mL}\end{array}$ & $\mathrm{SE}^{3}$ & $\begin{array}{l}\text { Minimum, } \\
\mathrm{mg} / 100 \mathrm{~mL}\end{array}$ & $\begin{array}{l}\text { Maximum, } \\
\mathrm{mg} / 100 \mathrm{~mL}\end{array}$ \\
\hline \multirow[t]{5}{*}{ Cholesterol $^{\mathrm{a}}$} & Control & 7 & 12.96 & 0.28 & 11.71 & 13.73 \\
\hline & $\mathrm{OP}$ & 1 & 13.66 & $\mathrm{NA}$ & 13.66 & 13.66 \\
\hline & SP & 3 & 10.09 & 0.21 & 9.68 & 10.31 \\
\hline & CSP & 1 & 11.16 & NA & 11.16 & 11.16 \\
\hline & Average & & 12.15 & 0.43 & 9.68 & 13.73 \\
\hline \multirow[t]{5}{*}{ Lathosterol } & Control & 7 & 0.07 & $<0.02$ & 0.06 & 0.09 \\
\hline & $\mathrm{OP}$ & 1 & 0.11 & NA & 0.11 & 0.11 \\
\hline & $\mathrm{SP}$ & 3 & 0.06 & $<0.02$ & 0.05 & 0.06 \\
\hline & CSP & 1 & 0.05 & NA & 0.05 & 0.05 \\
\hline & Average & & 0.07 & $<0.02$ & 0.05 & 0.11 \\
\hline \multirow[t]{5}{*}{ Campesterol } & Control & 7 & 0.04 & $<0.02$ & 0.03 & 0.04 \\
\hline & $\mathrm{OP}$ & 1 & 0.05 & NA & 0.05 & 0.05 \\
\hline & $\mathrm{SP}$ & 3 & 0.05 & $<0.02$ & 0.04 & 0.06 \\
\hline & CSP & 1 & 0.04 & NA & 0.04 & 0.04 \\
\hline & Average & & 0.04 & $<0.02$ & 0.03 & 0.06 \\
\hline \multirow[t]{5}{*}{ Lanosterol } & Control & 7 & 0.19 & $<0.02$ & 0.15 & 0.23 \\
\hline & $\mathrm{OP}$ & 1 & 0.26 & NA & 0.26 & 0.26 \\
\hline & $\mathrm{SP}$ & 3 & 0.21 & 0.02 & 0.16 & 0.24 \\
\hline & CSP & 1 & 0.11 & NA & 0.11 & 0.11 \\
\hline & Average & & 0.19 & $<0.02$ & 0.11 & 0.26 \\
\hline
\end{tabular}

${ }^{\mathrm{a}}$ All cholesterol concentrations were significantly different $(P<0.05)$. Cholesterol $P$-values: a and $\mathrm{b}=0.001$.

${ }^{1}$ Total phytosterols, campestanol, stigmasterol, stigmastanol, and $\beta$-sitosterol were less than the limit of reporting.

${ }^{2} \mathrm{OP}=$ omega protected; $\mathrm{SP}=$ sterol protected CSP $=$ canola-soybean protected.

${ }^{3}$ Not applicable. 
control groups and diets containing maize silage, maize grain, canola meal, DGM, and high-sterol rumen-protected feeds. The mode of feed offering was also shown to influence the levels of these sterols. The safe and beneficial recommended levels of phytosterol consumption by many food authorities is approximately 2,000 mg/d (Lichtenstein and Deckelbaum, 2001; Kritchevsky and Chen, 2005). However, the levels determined in this study were less than $0.12 \mathrm{mg} / 100 \mathrm{~mL}$, which is much lower than some fortified levels of $300 \mathrm{mg} / 100 \mathrm{~mL}$ in milk, which would require the consumption of $600 \mathrm{~mL}$ of milk to reach the target level (Pollak, 1953; Gerson et al., 1961; Miettinen et al., 1995; Carr et al., 2010; Truswell, 2010).

Of all the feeding experiments, the formulated SP and CSP feeding types resulted in the production of milk with a reduced cholesterol content. However, the phytosterol content in the milk produced under any of the formulated feeding programs was unchanged. In addition, the results also indicate that the phytosterol transfer from feed to the milk was not direct for the rumen-protected feed, unlike the transfer of n-3 fatty acid to milk that has previously been reported (Ashes et al., 1992; Gulati et al., 1997).

Overall, our results demonstrate that the feeding of diets containing high amounts of phytosterols has an insignificant effect on the phytosterol content of milk. Thus, the feeding of phytosterol-rich feeds to cattle to enhance the phytosterol concentrations in milk cannot be recommended. In addition, dairy industries worldwide are generally highly regulated, with milk carefully homogenized, pasteurized, and fortified to maintain consistent quality control. Thus, any natural fortification achieved on one farm will most likely be diluted during the postfarm processing of milk. These expectations were based on the results of previous studies that reported changes in the fatty acid profile as a result of feeding studies, and given that phytosterol fatty acid esters are a common sterol conjugate found in cattle feed (Dutta, 2004; Hristov et al., 2011; Samková et al., 2014).

\section{CONCLUSIONS}

The results of this research indicated total phytosterol content in milk cannot be enhanced through feed trials conducted in the experiments. Although some minor changes were observed with the levels of some individual sterols, overall natural fortification of phytosterols in milk was not achieved through these feeding trials. However, some changes were observed with respect to the cholesterol levels for the formulated sterol protected and canola-soybean oil sterol protected feed, with 22 and $11 \%$ reductions, respectively, when compared with the control diet.

\section{ACKNOWLEDGMENTS}

The authors gratefully acknowledge the support of Dairy Australia and Agriculture Victoria.

\section{REFERENCES}

Akbaridoust, G., T. Plozza, V. C. Trenerry, W. J. Wales, M. J. Auldist, F. R. Dunshea, and S. Ajlouni. 2014. Influence of different systems for feeding supplements to grazing dairy cows on milk fatty acid composition. J. Dairy Res. 81:156-163. https://doi.org/ 10.1017/S002202991400003X.

Aprianita, A., O. N. Donkor, P. J. Moate, S. R. O. Williams, M. J. Auldist, J. S. Greenwood, M. C. Hannah, W. J. Wales, and T. Vasiljevic. 2014. Effects of dietary cottonseed oil and tannin supplements on protein and fatty acid composition of bovine milk. J. Dairy Res. 81:183-192. https://doi.org/10.1017/ S0022029914000065.

Ashes, J. R., P. St. Vincent Welch, S. K. Gulati, T. W. Scott, G. H. Brown, and S. Blakeley. 1992. Manipulation of the fatty acid composition of milk by feeding protected canola seeds. J. Dairy Sci. 75:1090-1096. https://doi.org/10.3168/jds.S0022-0302(92)77853 -9 .

Auldist, M. J., L. C. Marett, J. S. Greenwood, M. Hannah, J. L. Jacobs, and W. J. Wales. 2013. Effects of different strategies for feeding supplements on milk production responses in cows grazing a restricted pasture allowance. J. Dairy Sci. 96:1218-1231. https:/ /doi.org/10.3168/jds.2012-6079.

Auldist, M. J., L. C. Marett, J. S. Greenwood, M. M. Wright, M. Hannah, J. L. Jacobs, and W. J. Wales. 2014. Replacing wheat with canola meal in a partial mixed ration increases the milk production of cows grazing at a restricted pasture allowance in spring. Anim. Prod. Sci. 54:869-878. https://doi.org/10.1071/AN13154.

Baldinger, L., W. Zollitsch, and W. F. Knaus. 2014. Maize silage and Italian ryegrass silage as high-energy forages in organic dairy cow diets: Differences in feed intake, milk yield and quality, and nitrogen efficiency. Renew. Agric. Food Syst. 29:378-387. https://doi .org/10.1017/S1742170513000252.

Ben-Ishay, N., H. Oknin, D. Steinberg, Z. Berkovich, R. Reifen, and M. Shemesh. 2017. Enrichment of milk with magnesium provides healthier and safer dairy products. npj Biofilms Microbiomes 3:24. https://doi.org/10.1038/s41522-017-0032-3.

Berciano, S., and J. M. Ordovás. 2014. Nutrition and cardiovascular health. Rev. Esp. Cardiol. (Engl. Ed.) 67:738-747.

Carr, T. P., M. M. Ash, and A. W. Brown. 2010. Cholesterol-lowering phytosterols: Factors affecting their use and efficacy. Nutr. Diet. Suppl. 2:59-72. https://doi.org/10.2147/NDS.S10974.

Chang, Y. C., C. H. Chen, and M. C. Lin. 2012. The macronutrients in human milk change after storage in various containers. Pediatr. Neonatol. 53:205-209. https://doi.org/10.1016/j.pedneo.2012.04 .009 .

Duong, S., N. Strobel, S. Buddhadasa, K. Stockham, M. J. Auldist, W. J. Wales, P. J. Moate, J. D. Orbell, and M. J. Cran. 2018. Influence of acid hydrolysis, saponification and sample clean-up on the measurement of phytosterols in dairy cattle feed using GC-MS and GC with flame ionization detection. J. Sep. Sci. 41: 3467-3476. https://doi.org/10.1002/jssc.201800484.

Dutta, P. C. 2004. Phytosterols as Functional Food Components and Nutraceuticals. CRC Press, Boca Raton, FL.

Egger, P., G. Holzer, S. Segato, E. Werth, F. Schwienbacher, G. Peratoner, I. Andrighetto, and A. Kasal. 2009. Effects of oilseed supplements on milk production and quality in dairy cows fed a hay-based diet. Ital. J. Anim. Sci. 6:395-406. https://doi.org/10 $.4081 /$ ijas.2007.395. 
Food Standards Australia New Zealand. 2010. NUTTAB 2010 Electronic Database Files. Accessed Oct. 19, 2018. http://www .foodstandards.gov.au/science/monitoringnutrients/nutrientables/ nuttab/Pages/NUTTAB-2010-electronic-database-files.aspx.

García-Lara, N. R., D. Escuder-Vieco, O. García-Algar, J. De la Cruz, D. Lora, and C. Pallás-Alonso. 2012. Effect of freezing time on macronutrients and energy content of breastmilk. Breastfeed. Med. 7:295-301. https://doi.org/10.1089/bfm.2011.0079.

Gerson, T., F. B. Shorland, and Y. Adams. 1961. The effects of corn oil on the amounts of cholesterol and the excretion of sterol in the rat. Biochem. J. 81:584-591.

Gómez, I., J. A. Mendizabal, M. V. Sarriés, K. Insausti, P. Albertí, C. Realini, M. Pérez-Juan, M. A. Oliver, A. Purroy, and M. J. Beriain. 2015. Fatty acid composition of young Holstein bulls fed whole linseed and rumen-protected conjugated linoleic acid enriched diets. Livest. Sci. 180:106-112. https://doi.org/10.1016/j .livsci.2015.07.023.

Goncalves, A., B. Gleize, R. Bott, M. Nowicki, M. J. Amiot, D. Lairon, P. Borel, and E. Reboul. 2011. Phytosterols can impair vitamin D intestinal absorption in vitro and in mice. Mol. Nutr. Food Res. 55:S303-S311. https://doi.org/10.1002/mnfr.201100055.

Gorban, A. M. S., and O. M. Izzeldin. 1999. Study on cholesteryl ester fatty acids in camel and cow milk lipid. Int. J. Food Sci. Technol. 34:229-234. https://doi.org/10.1046/j.1365-2621.1999.00254.x.

Gulati, S. K., J. R. Ashes, and T. W. Scott. 1999. Hydrogenation of eicosapentaenoic and docosahexaenoic acids and their incorporation into milk fat. Anim. Feed Sci. Technol. 79:57-64. https://doi .org/10.1016/S0377-8401(99)00010-3.

Gulati, S. K., S. M. Kitessa, J. R. Ashes, E. Fleck, E. B. Byers, Y. G. Byers, and T. W. Scott. 2000. Protection of conjugated linoleic acids from ruminal hydrogenation and their incorporation into milk fat. Anim. Feed Sci. Technol. 86:139-148. https://doi.org/10 $.1016 / \mathrm{S} 0377-8401(00) 00170-\mathrm{X}$

Gulati, S. K., T. W. Scott, and J. R. Ashes. 1997. In vitro assessment of fat supplements for ruminants. Anim. Feed Sci. Technol. 64:127-132. https://doi.org/10.1016/S0377-8401(96)01063-2.

Gylling, H., J. Plat, S. Turley, H. N. Ginsberg, L. Ellegård, W. Jessup, P. J. Jones, D. Lütjohann, W. Maerz, L. Masana, G. Silbernagel, B. Staels, J. Borén, A. L. Catapano, G. De Backer, J. Deanfield, O. S. Descamps, P. T. Kovanen, G. Riccardi, L. Tokgözoglu, and M. J. Chapman. 2014. Plant sterols and plant stanols in the management of dyslipidaemia and prevention of cardiovascular disease. Atherosclerosis 232:346-360. https://doi.org/10.1016/j atherosclerosis.2013.11.043.

Hristov, A. N., C. Domitrovich, A. Wachter, T. Cassidy, C. Lee, K. J. Shingfield, P. Kairenius, J. Davis, and J. Brown. 2011. Effect of replacing solvent-extracted canola meal with high-oil traditional canola, high-oleic acid canola, or high-erucic acid rapeseed meals on rumen fermentation, digestibility, milk production, and milk fatty acid composition in lactating dairy cows. J. Dairy Sci. 94:4057-4074. https://doi.org/10.3168/jds.2011-4283.

Huang, J., M. Xu, Y. J. Fang, M. S. Lu, Z. Z. Pan, W. Q. Huang, Y. M. Chen, and C. X. Zhang. 2017. Association between phytosterol intake and colorectal cancer risk: A case-control study. Br. J. Nutr. 117:839-850. https://doi.org/10.1017/S0007114517000617.

Jäpelt, R. B., and J. Jakobsen. 2013. Vitamin D in plants: A review of occurrence, analysis, and biosynthesis. Front. Plant Sci. 4:136. https://doi.org/10.3389/fpls.2013.00136.

Jensen, R. G. 2002. The composition of bovine milk lipids: January 1995 to December 2000. J. Dairy Sci. 85:295-350. https://doi.org/ 10.3168/jds.S0022-0302(02)74079-4.

Kalač, P., and E. Samková. 2010. The effects of feeding various forages on fatty acid composition of bovine milk fat: A review. Czech J. Anim. Sci. 55:521-537.

Kritchevsky, D., and S. C. Chen. 2005. Phytosterols-health benefits and potential concerns: A review. Nutr. Res. 25:413-428. https:// doi.org/10.1016/j.nutres.2005.02.003.

Leduc, M., M.-P. Létourneau-Montminy, R. Gervais, and P. Y. Chouinard. 2017. Effect of dietary flax seed and oil on milk yield, gross composition, and fatty acid profile in dairy cows: A meta-analysis and meta-regression. J. Dairy Sci. 100:8906-8927. https://doi.org/ $10.3168 /$ jds. $2017-12637$.

Lichtenstein, A. H., and R. J. Deckelbaum. 2001. Stanol/sterol ester-containing foods and blood cholesterol levels: A statement for healthcare professionals from the nutrition committee of the council on nutrition, physical activity, and metabolism of the American Heart Association. Circulation 103:1177-1179. https://doi.org/10 .1161/01.CIR.103.8.1177.

Meignan, T., C. Lechartier, G. Chesneau, and N. Bareille. 2017. Effects of feeding extruded linseed on production performance and milk fatty acid profile in dairy cows: A meta-analysis. J. Dairy Sci. 100:4394-4408. https://doi.org/10.3168/jds.2016-11850.

Mellanen, P., T. Petänen, J. Lehtimäki, S. Mäkelä, G. Bylund, B. Holmbom, E. Mannila, A. Oikari, and R. Santti. 1996. Wood-derived estrogens: Studies in vitro with breast cancer cell lines and in vivo in trout. Toxicol. Appl. Pharmacol. 136:381-388. https:// doi.org/10.1006/taap.1996.0046.

Miettinen, T. A., P. Puska, H. Gylling, H. Vanhanen, and E. Vartiainen. 1995. Reduction of serum cholesterol with sitostanol-ester margarine in a mildly hypercholesterolemic population. N. Engl. J. Med. 333:1308-1312. https://doi.org/10.1056/NEJM199511163332002.

Moate, P. J., S. R. O. Williams, V. A. Torok, M. C. Hannah, B. E. Ribaux, M. H. Tavendale, R. J. Eckard, J. L. Jacobs, M. J. Auldist, and W. J. Wales. 2014. Grape marc reduces methane emissions when fed to dairy cows. J. Dairy Sci. 97:5073-5087. https://doi .org/10.3168/jds.2013-7588.

Moreau, R. A., L. Nyström, B. D. Whitaker, J. K. Winkler-Moser, D. J. Baer, S. K. Gebauer, and K. B. Hicks. 2018. Phytosterols and their derivatives: Structural diversity, distribution, metabolism, analysis, and health-promoting uses. Prog. Lipid Res. 70:35-61. https://doi.org/10.1016/j.plipres.2018.04.001.

Ostlund, R. E. 2002. Phytosterols in human nutrition. Annu. Rev. Nutr. 22:533-549. https://doi.org/10.1146/annurev.nutr.22.020702 .075220 .

Ostlund, R. E. 2007. Phytosterols, cholesterol absorption and healthy diets. Lipids 42:41-45. https://doi.org/10.1007/s11745-006-3001-9.

Ostlund, R. E., C. A. Spilburg, and W. F. Stenson. 1999. Sitostanol administered in lecithin micelles potently reduces cholesterol absorption in humans. Am. J. Clin. Nutr. 70:826-831.

Pfrimer, K., E. Ferriolli, P. L. Takeuchi, M. S. V. Salles, A. SaranNetto, M. A. Zanetti, L. C. Roma-Junior, C. B. M. Braga, F. A. Domenici, Y. M. L. Valim, A. B. P. Paschoalato, L. F. Marchi, A. E. C. S. Azzolini, E. A. Donadi, E. Martinez, and H. Vannucchi. 2018. Effects of the consumption of milk biofortified with selenium, vitamin $\mathrm{E}$, and different fatty acid profile on immune response in the elderly. Mol. Nutr. Food Res. 62:1-7. https://doi .org/10.1002/mnfr.201700307.

Phang, M., and M. Garg. 2014. Chapter 16-Combined phytosterol and fish oil therapy for lipid lowering and cardiovascular health. Pages 437-463 in Food Structures, Digestion and Health. Acad. Press, Elsevier, London, UK. https://doi.org/10.1016/B978-0-12 -404610-8.00016-5.

Piironen, V., J. Toivo, and A. M. Lampi. 2002a. Plant sterols in cereals and cereal products. Cereal Chem. 79:148-154. https://doi.org/10 .1094/CCHEM.2002.79.1.148

Piironen, V., J. Toivo, and A. M. Lampi. 2002b. New data for cholesterol contents in meat, fish, milk, eggs and their products consumed in Finland. J. Food Compos. Anal. 15:705-713. https://doi .org/10.1006/jfca.2002.1095.

Pineda, A., and F. C. Cardoso. 2015. Effects of rumen-protected choline with calcium salts of long chain fatty acids on milk yield and milk composition of middle and late lactation Holstein cows. Livest. Sci. 175:37-46. https://doi.org/10.1016/j.livsci.2015.02.005.

Pollak, O. J. 1953. Reduction of blood cholesterol in man. Circulation 7:702-706. https://doi.org/10.1161/01.CIR.7.5.702.

Reklewska, B., A. Oprządek, Z. Reklewski, L. Panicke, B. Kuczyńska, and J. Oprzadek. 2002. Alternative for modifying the fatty acid composition and decreasing the cholesterol level in the milk of cows. Pages 235-243 in Livestock Production Science. Elsevier, Amsterdam, the Netherlands. 
Rideout, T. C., C. P. F. Marinangeli, and A. B. Awad. 2012. Regulatory approval of plant sterols in Canada: Implications for health care and clinical practice. Can. J. Diet. Pract. Res. 73:31-34. https:// doi.org/10.3148/73.1.2012.31.

Ruibal-Mendieta, N. L., R. Rozenberg, D. L. Delacroix, G. Petitjean, A. Dekeyser, C. Baccelli, C. Marques, N. M. Delzenne, M. Meurens, J. L. Habib-Jiwan, and J. Quetin-Leclercq. 2004. Spelt (Triticum spelta L.) and winter wheat (Triticum aestivum L.) wholemeals have similar sterol profiles, as determined by quantitative liquid chromatography and mass spectrometry analysis. J. Agric. Food Chem. 52:4802-4807. https://doi.org/10.1021/jf049772v.

Samková, E., J. Čertíková, J. Špička, O. Hanuš, T. Pelikánová, and M. Kváč. 2014. Eighteen-carbon fatty acids in milk fat of Czech Fleckvieh and Holstein cows following feeding with fresh lucerne (Medicago sativa L.). Anim. Sci. Pap. Rep. 32:209-218.

Steinshamn, H. 2010. Effect of forage legumes on feed intake, milk production and milk quality-A review. Anim. Sci. Pap. Rep. 28:195-206.

Strzałkowska, N., A. Jóźwik, E. Bagnicka, J. Krzyżewski, R. G. Cooper, and J. O. Horbańczuk. 2010. Factors affecting the cholesterol content of milk of cows fed conserved feeds in a TMR system throughout the year. Mljekarstvo 60:273-279.

Truswell, A. S. 2010. Cholesterol and Beyond: The Research on Diet and Coronary Heart Disease 1900-2000. Springer Science \& Business Media, Dordrecht, the Netherlands.
Waalkens-Berendsen, D. H., A. P. M. Wolterbeek, M. V. W. Wijnands, M. Richold, and P. A. Hepburn. 1999. Safety evaluation of phytosterol esters. Part 3. Two-generation reproduction study in rats with phytosterol esters - A novel functional food. Food Chem. Toxicol. 37:683-696. https://doi.org/10.1016/S0278-6915(99)00056-3.

Wang, D. M., C. Wang, H. Y. Liu, J. X. Liu, and J. D. Ferguson. 2013 Effects of rumen-protected $\gamma$-aminobutyric acid on feed intake, lactation performance, and antioxidative status in early lactating dairy cows. J. Dairy Sci. 96:3222-3227. https://doi.org/10.3168/ jds.2012-6285.

Yeh, E. B., D. M. Barbano, and M. A. Drake. 2017. Vitamin fortification of fluid milk. J. Food Sci. 82:856-864. https://doi.org/10 $.1111 / 1750-3841.13648$.

Zhao, L., X.-J. Chen, J. Zhu, Y.-B. Xi, X. Yang, L.-D. Hu, H. Ouyang, S. H. Patel, X. Jin, D. Lin, F. Wu, K. Flagg, H. Cai, G. Li, G. Cao, Y. Lin, D. Chen, C. Wen, C. Chung, Y. Wang, A. Qiu, E. Yeh, W. Wang, X. Hu, S. Grob, R. Abagyan, Z. Su, H. C. Tjondro, X.-J. Zhao, H. Luo, R. Hou, J. Jefferson, P. Perry, W. Gao, I. Kozak, D. Granet, Y. Li, X. Sun, J. Wang, L. Zhang, Y. Liu, Y.-B. Yan, and K. Zhang. 2015. Lanosterol reverses protein aggregation in cataracts. Nature 523:607. 